ARTICLE

\title{
Is expressivism theologically acceptable?
}

\section{St.John Lambert ${ }^{1}$ (D)}

Received: 27 October 2020 / Accepted: 18 February 2021 / Published online: 4 March 2021

(c) The Author(s) 2021

\begin{abstract}
As a matter of fact, few, if any, theists have been expressivists about morality. This is probably because expressivism is thought to have unacceptable theological implications. That is, it is thought to imply (1) that God's goodness depends on our desirelike states, (2) that God's goodness is not a real property, (3) that it is not true that God is good, and (4) that God's moral thoughts have no explanation. I argue that expressivism has no such implications and conclude that expressivism is theologically acceptable.
\end{abstract}

Keywords Expressivism · Theism · Mind-dependence · Properties · Truth · Explanation

\section{Theism and expressivism}

It is a striking fact that while many non-theists have been expressivists about morality, few, if any, theists have been expressivists about morality. This is probably because expressivism is thought to have unacceptable theological implications, at least among theists. For it is unclear why theists would disproportionately reject this view unless it were thought to have such implications. This paper considers whether expressivism has unacceptable theological implications. I'll start by clarifying what theism and expressivism are. ${ }^{1}$

\footnotetext{
1 As far as I know, no contemporary theists are expressivists about morality. All contemporary theists (that I know of) are moral realists. For example, Robert Adams, William Alston, Robert Audi, David Baggett, Paul Copan, William Lane Craig, Stephen Evans, John Hare, Mark Linville, Tim Mawson, Christian Miller, J. P. Moreland, Mark Murphy, Alvin Plantinga, Philip Quinn, Richard Swinburne, Jerry Walls, Edward Wierenga, Linda Zagzebski, and so on, are all moral realists. This is not to say, of course, that theists don't disagree about metaethical matters, for they disagree about what kind of realism to accept. Rather, it is to say that there is widespread agreement among theists that moral realism is true and that expressivism is false.
}

St.John Lambert

sj11g13@soton.ac.uk

1 Philosophy Department, University of Southampton, Highfield Rd, Southampton SO17 1BF, UK 
Theism is the view that God exists. For the purpose of this paper, I'll accept a traditional view of God, according to which God is an omnipotent, omniscient, perfectly good being, who is the creator and sustainer of all things. I'll thus consider whether expressivism is theologically acceptable from the perspective of this traditional form of theism.

Expressivism, by contrast, is a view about moral thought. It holds that moral thoughts, such as the thought that lying is wrong, are fundamentally different from descriptive thoughts, such as the thought that snow is white. Whereas descriptive thoughts are belief-like states that represent the world as being a certain way, moral thoughts are desire-like states that motivate us to act, or respond, in certain ways. Take the thought that lying is wrong. According to expressivism, this thought is not one that represents lying as being a certain way, or as having a certain property, but one that motivates us not to lie, or to blame those who do. Expressivism thus holds that moral thoughts are desire-like, motivational states, rather than belief-like, representational states. In other words, it holds that moral thoughts are states like approvals, desires, plans, preferences, intentions, norm-acceptances, and so on. ${ }^{2}$

Expressivism can be contrasted with moral realism. This view, as I understand it, holds that moral thoughts are belief-like states that represent moral properties, where moral properties are "ontologically committing" or "metaphysically real" moral features of reality. Take the thought that lying is wrong. According to realism, this thought represents lying as having the moral property of being wrong. If lying instantiates this property, then this thought accurately represents the world. Importantly, realism also holds that moral properties are instantiated in the world. It thus holds that at least some moral thoughts accurately represent the world. In contrast to realism, expressivism denies that ontologically committing moral properties are instantiated in the world, and that moral thoughts represent such properties. According to expressivism, to think that lying is wrong is not to represent lying as having some ontological property, but to be against lying. It is perhaps to disapprove of lying, or to plan not to lie, or to accept some norm that prohibits lying.

Expressivism, I should note, is also a view about moral language. It holds that moral sentences express desire-like states. For example, that 'lying is wrong' expresses disapproval of lying. Importantly, expressivism is distinct from speaker subjectivism, the view that moral sentences report or describe desire-like states. According to speaker subjectivism, in saying that lying is wrong, I report my disapproval of lying. That is, I claim that I disapprove of lying. But expressivism is not speaker subjectivism. For expressivism denies that moral sentences are in the business of reporting or describing anything, much less our own psychological states (Blackburn, 1998, p. 50; Gibbard, 1990, pp. 7-8). According to expressivism, in saying that lying is wrong, I do not report or describe my disapproval of lying, I

\footnotetext{
2 Throughout this paper, I use the term 'moral thought' to refer to the mental state expressed by the sincere utterance of a moral sentence. Thus, on my terminology, the moral thought that lying is wrong is the mental state (whatever it may be) that is expressed by the sincere utterance of the sentence 'lying is wrong'.
} 
express my disapproval of lying. So 'lying is wrong' means something like 'Boo lying!', on expressivism. It does not mean 'I disapprove of lying'.

Now that we have clarified what theism and expressivism are, we should briefly consider why theists might want to endorse expressivism before considering whether it is theologically acceptable.

\section{Why theists might endorse expressivism}

There are three arguments that are worth discussing. The first two are general metaethical arguments for expressivism that can be endorsed by theists as much as nontheists. The third is a specific theological argument for expressivism that only theists can endorse.

The first argument concerns the motivational powers of moral thoughts. This argument states that moral thoughts can themselves motivate us to act-for example, the thought that lying is wrong can itself motivate me not to lie. But beliefs can't themselves motivate us to act, because beliefs can only motivate when combined with appropriate desire-like states-for example, the belief that it is raining can only motivate me to put up my umbrella when combined with an appropriate desirelike state, such as the desire to not get wet. If this is true, then it follows that moral thoughts are not beliefs. Moreover, if only desire-like states can themselves motivate us to act, then it follows that moral thoughts are such states. ${ }^{3}$

The second argument concerns the economy of expressivism. This argument states that expressivism is more parsimonious than its main rival, moral realism, because expressivism does not postulate the existence of "ontologically committing" or "metaphysically real" moral properties. It only postulates the existence of certain desire-like states (Blackburn, 1984, p. 182). Expressivism is thus less "expensive" than moral realism in terms of its metaphysics and epistemology, and so has decided metaphysical and epistemological advantages over it. Realists, for example, but not expressivists, must answer such difficult questions as 'What are moral properties?', 'Are they reducible or irreducible?', 'How do we come to reliably track them?', and 'How do our words and thoughts manage to refer and be about them?'. As a result of this, expressivism is preferable to realism from the standpoint of metaphysics and epistemology, and this counts as an argument in its favour. ${ }^{4}$

\footnotetext{
3 For versions of this argument, see Hare (1952, p. 1); Blackburn (1984, pp. 187-189); Gibbard (2003, pp. 8-13).

4 One might object that since theists already have a rather "expensive" metaphysic, they shouldn't take the economy of expressivism to be an argument in its favour. But this is not right. If expressivism explains the metaethical data just as well as realism does, and it is more parsimonious, then everyone, theist and non-theist alike, should take that to be an argument in its favour. So the economy of expressivism is an argument in expressivism's favour, even on theism. Alternatively, one might object that since theism helps realists answer the difficult questions they face, the argument that expressivism is preferable to realism is undermined by theism. But this is not obviously true. Moreover, theism seems to introduce further difficult questions for realists to answer, such as 'What is the relation between God and realist moral properties?', among many others.
} 
The third and final argument concerns the metaethical implications of the doctrine of divine sovereignty, according to which everything that exists (other than God) depends for its existence on God. This argument states that theists who accept this doctrine are committed to the claim that if moral realism is true and there are ontologically committing moral properties, then such properties depend on God (Murphy, 2011; Quinn, 1990). But, the argument goes, such properties do not depend on God because it's not the case that actions are right, wrong, good, and bad, because God makes them so (Wielenberg, 2014). If this is right, then theists who accept this doctrine are committed to the falsity of moral realism: there are no ontologically committing moral properties, because if there were, they would implausibly depend on God. The upshot of this is that such theists should deny that moral thoughts are belief-like states that represent ontologically committing moral properties (on pain of being committed to an error theory according to which moral thoughts are systematically mistaken because they represent properties that do not exist). They should accept instead that moral thoughts are desire-like states that do not represent such properties.

These arguments each involve their fair share of controversial claims, and I shall not attempt to defend them here. My aim in mentioning them is simply to point out that there are prima facie good arguments for expressivism that theists can endorse. Now that we have outlined these arguments, we can move on to consider whether expressivism is theologically acceptable.

\section{Why expressivism might be theologically unacceptable}

As far as I can see, there are four reasons why expressivism might be theologically unacceptable. They are that expressivism implies that:

1. God's goodness depends on our desire-like states.

2. God's goodness is not a real property.

3. It is not true that God is good.

4. God's moral thoughts have no explanation.

In what follows, I argue that expressivism has no such implications: the following sections rebut the above claims in turn. Since expressivism has no unacceptable theological implications, I conclude that expressivism is theologically acceptable. If I am right, then expressivism should be considered a live option for theists.

Two preliminary comments before we proceed. First, it is important to note that I am not arguing that theists should be expressivists. I am only arguing that expressivism is theologically acceptable. This distinction is important to grasp because it might be that theists should reject expressivism, even if expressivism is theologically acceptable. After all, expressivism might be unacceptable for non-theological reasons, in which case theists should reject it, even if it is theologically acceptable. For example, the Frege-Geach problem might show that expressivism can't account for the meaning of moral sentences in embedded contexts, in which case theists 
should reject the view, even if it is theologically acceptable. That said, while I'm not arguing that theists should be expressivists, I am arguing that theists should consider expressivism a live option. To that extent, I am laying the foundation for arguing that theists should be expressivists. ${ }^{5}$

Second, because there is no consensus among expressivists as to what desire-like states moral thoughts are, I shall stipulatively call the moral thought that X is good, approval of $X$. In so doing, I do not intend to imply that this is what the thought really is. I am simply using 'approval' as a placeholder for the desire-like state (whatever it may be) that thinking that $\mathrm{X}$ is good is, on expressivism. Thus, on my terminology, to think that $\mathrm{X}$ is good is to approve of $\mathrm{X}$, and so the sentence ' $\mathrm{X}$ is good' expresses approval of $\mathrm{X}$. With these comments out of the way, we can move on to consider the first claim.

\section{Expressivism and mind-dependence}

According to the first claim, expressivism implies that God's goodness depends on our approvals. If this is true, then expressivism has unacceptable theological implications because no theist will want to say that God is good because we approve of him. For God's goodness does not in any way depend on us-were we not to approve of God, God would still be good. Fortunately, expressivism does not imply that God's goodness depends on our approvals. We can see this by making two points about expressivism.

The first is that expressivism is not a view about what it is for something to be good. It is only a view about what it is to think that something is good (Blackburn, 1998, p. 50; Gibbard, 1990, p. 8). In other words, expressivism is not the view that $\mathrm{X}$ is good just in case and because one approves of $\mathrm{X}$. Rather, it is the view that one thinks that $\mathrm{X}$ is good just in case and because one approves of $\mathrm{X}$-to think that $\mathrm{X}$ is good just is, or consists in, approving of X. So expressivism does not imply that were we not to approve of $\mathrm{X}, \mathrm{X}$ would not be good. It only implies that were we not to approve of $\mathrm{X}$, we would not think that $\mathrm{X}$ is good.

The second point is that the expression relation ensures that expressivism does not imply that goodness depends on our approvals. The expression relation, we can note, is a stipulative relation within expressivism. It is that semantically significant relation between 'snow is white' and the belief that snow is white-_ 'snow is white' is said to express the belief that snow is white (Schroeder, 2010, p. 73). Expressivism thus holds that the relation between ' $\mathrm{X}$ is good' and approval of $\mathrm{X}$ is exactly the same as the relation between 'snow is white' and the belief that snow is white, for ' $\mathrm{X}$ is good' is said to express approval of $\mathrm{X}$. This ensures that expressivism

\footnotetext{
5 To be clear, since I'm not arguing that expressivism is true, I am not here concerned with objections to the effect that expressivism is false. I am only here concerned with objections to the effect that expressivism is theologically unacceptable. Moreover, since I'm not arguing that expressivism is theologically superior to all other metaethical views, I am not here concerned with objections to the effect that other metaethical views have theological advantages over expressivism. I am only here concerned with objections to the effect that expressivism is theologically unacceptable.
} 
does not imply that goodness is mind-dependent. For by saying that ' $\mathrm{X}$ is good' is related to approval of $\mathrm{X}$ in exactly the same way that 'snow is white' is related to the belief that snow is white, expressivism ensures that goodness no more depends on our approvals than whiteness depends on our beliefs. In other words, since 'snow is white' and the belief that snow is white are related in such a way that whiteness does not depend on our beliefs, and expressivism says that ' $\mathrm{X}$ is good' and approval of $\mathrm{X}$ are related in exactly the same way, the view is guaranteed not to imply that goodness depends on our approvals. ${ }^{6}$

The first claim is thus false. Expressivism does not imply that God's goodness depends on our approvals. It only implies that were we not to approve of God, we would not think that God is good. If expressivism has unacceptable theological implications, it must be because it implies something else. This brings us on to the second claim. ${ }^{7}$

\section{Expressivism and properties}

According to the second claim, expressivism implies that God's goodness is not a real property - a property that God really has. If this is true, then expressivism has unacceptable theological implications because all theists will want to say that God really is good. Fortunately, expressivism does not imply anything that conflicts with this.

We should start by considering what moral property-talk might amount to on expressivism. A natural view for expressivists to endorse is minimalism about properties, according to which to say that $\mathrm{X}$ has the property of being $\mathrm{F}$ is just to say

\footnotetext{
${ }^{6}$ For further discussion of this point, see Schroeder (2010, pp. 162-164; 2014).

7 But what does goodness depend on, according to expressivism? It is important to see that expressivism does not answer this question. Just as it does not say what things are good, it does not say what things goodness depends on. Expressivism does say, however, what things one thinks goodness depends on. According to expressivism, what one thinks goodness depends on is determined by one's reasons for approving. For example, if one approves of X because $\mathrm{X}$ promotes happiness, then one will think that X's goodness depends on its promoting happiness. Similarly, if one approves of X because X is commanded by God, then one will think that X's goodness depends on its being commanded by God. The issue of what goodness depends on is thus a first-order moral issue, on expressivism-it is the issue of what to approve of and why. Because of this, expressivism can make sense of various moral theories that theists might accept, such as divine command theory. For according to expressivism, if one approves of things because God commands them, then one will think that God's commands are what make things good. In other words, one will think that divine command theory about goodness is true. The issue of whether divine command theory is true is thus a first-order moral issue, on expressivism. Consequently, whether one thinks that divine command theory is true will depend on one's own first-order moral views. For further discussion of this, see Sinclair (2008, 2020, pp. 62-64, 67-68); Berker (2020). But what about claims of moral mind-independence, such as 'God would be good whether or not we approve of him'? Expressivism can make sense of such claims by treating them as expressions of attitude. According to expressivism, if one approves of God even when one considers worlds in which no one approves of him, then one will think that God is good whether or not we approve of him. According to expressivism, it is this categorical approval of God that is expressed when we say 'God would be good whether or not we approve of him' (cf. Golub, 2017, p. 1388). For further discussion, see Blackburn (1984, pp. 217-219; 1993, pp. 152-153, 172-174; 1998, pp. 74, 296, 311-312); Gibbard (1990, pp. 164-166).
} 
that $\mathrm{X}$ is $\mathrm{F}$. According to minimalism, there is nothing more to saying that $\mathrm{X}$ has the property of being good than to saying that $\mathrm{X}$ is good. If this is right, then moral property-talk is nothing more than first-order moral-talk, on expressivism. For to say that $\mathrm{X}$ has the property of being good is just to say that $\mathrm{X}$ is good, which in turn is just to express approval of God. Consequently, if expressivism is true, then one who says that $\mathrm{X}$ has the property of being good incurs no ontological commitment in doing so. For in saying that $\mathrm{X}$ has the property of being good, one expresses approval of $\mathrm{X}$ in just the same way one does when one says that $\mathrm{X}$ is good.

Let's grant for the sake of argument that minimalism is true. Why think that the second claim is true-that expressivism implies that God's goodness is not a real property? The thought here is that expressivism implies this because only ontologically committing properties are real, and moral properties are not ontologically committing on expressivism, since one incurs no ontological commitment in saying that $\mathrm{X}$ has the property of being good. If this is right, then expressivism implies that God's goodness is not a real property. ${ }^{8}$

Expressivists should respond to this by denying that only ontologically committing properties are real. They should argue that moral properties are real despite not being ontologically committing. They should argue as follows. To say that a property is real is just to say that it is one that an object really has. But expressivists can affirm that objects really have the property of being good. For to say that $\mathrm{X}$ really has the property of being good is just to say that X really is good, and expressivists can affirm this first-order moral claim. Expressivists can thus affirm that God's goodness is a real property, because on expressivism, there is nothing more to saying that God's goodness is a real property than to saying that God really is good, and expressivists can affirm this first-order moral claim.

One might wonder whether the claim that God really is good is a first-order moral claim on expressivism. But clearly it is. For the claim is most naturally read as an emphatic first-order moral claim to the effect that God is good on expressivism- the word 'really' just adds an emphatic element to the first-order moral claim (cf. Blackburn, 1993, p. 157). One who emphatically approves of God thus affirms all that is properly meant by the claim that God really is good. Consequently, expressivists can affirm that God's goodness is a real property, even though it is not an ontologically committing one. ${ }^{9}$

Thus, if minimalism about properties is true, expressivists can affirm that God's goodness is a real property. But what if minimalism is false? In that case, expressivists should deny that there are moral properties, and so deny that God's goodness is a property. Expressivists should insist, however, that this is unproblematic. For they can point out that even if God's goodness is not a property, they can still affirm that God really is good. For they can do this by emphatically approving of God. Moreover, they can point out that since God's goodness is what is central to theism, and it

\footnotetext{
${ }^{8}$ I take ontologically committing properties to be metaphysically heavy properties. For discussion of metaphysical weight in metaethics, see Böddeling (2020).

9 Some philosophers might use the term 'real' to mean 'ontologically committing'. Expressivists should deny that God's goodness is a real property in this stipulative sense of the term.
} 
can still be affirmed on expressivism, their view should not be considered theologically problematic, even if it happens to rule out moral property-talk. So expressivism is theologically acceptable, even if minimalism is false.

Expressivism is thus theologically acceptable either way. If expressivism has unacceptable theological implications, it must be because it implies something else. This brings us on to the third claim. ${ }^{10}$

\section{Expressivism and truth}

According to the third claim, expressivism implies that 'God is good' is not true. If this is right, then expressivism has unacceptable theological implications because all theists will want to say that it is true that God is good. Fortunately, expressivists can affirm that 'God is good' is true, for they can do this by going deflationist about truth.

Deflationary theories of truth come in different forms, but the main idea is that to say that ' $\mathrm{P}$ ' is true is not to ascribe some substantive or robust property of truth to ' $\mathrm{P}$ ' (like correspondence). Rather, it's really just to say the underlying sentence. So, saying that ' $\mathrm{P}$ ' is true really just amounts to saying that $\mathrm{P}$ on such views. If deflationism is right, then expressivists can affirm that moral sentences, like 'God is good', are true. For moral truth-talk turns out to be nothing more than first-order moral talk on expressivism: to say that 'God is good' is true is just to say that God is good, which in turn is just to express approval of God. The third claim is thus false. Expressivism does not imply that 'God is good' is not true. For expressivists can affirm that 'God is good' is true by going deflationist about truth. ${ }^{11}$

At this point, one might worry that the theological plausibility of expressivism is hostage to the plausibility of deflationism. For if deflationism is false, then expressivists can't affirm that 'God is good' is true. There are two points to make in response to this worry.

\footnotetext{
${ }^{10}$ It is worth noting that the doctrine of divine simplicity might be incompatible with expressivism. For, according to that doctrine, God is identical with his nature or properties, including his goodness. This doctrine thus implies that God's goodness exists in the same ontologically committing or metaphysically heavy way that God exists, for God just $i$ s God's goodness. This implication seems to be at odds with expressivism, because expressivists take God's goodness to exist in only a non-ontologically committing or metaphysically light way. To be clear, this does not mean that expressivists can't take goodness to be part of God's nature. For they can claim that it is a conceptual truth that God is good, and so can claim that part of what it is to be God is to be good. According to expressivism, if it is a conceptual truth that God is good, then competent users of 'God' will only count a being as God if they think that being is good, that is, if they approve of that being.

11 What about more interesting uses of 'true', such as 'Everything God thinks is true'? Expressivists can understand these uses of 'true' in terms of the commitments they express (Ridge, 2014, pp. 200-203). According to this proposal, in saying that everything God thinks is true, I commit myself to accepting everything God thinks. So, if God thinks that X is good, I commit myself to accepting that X is good, that is, to approving of X. For further discussion, see Blackburn (1998, pp. 75-79, 318-319); Ridge (2014, pp. 193-224); Schroeder (2010, pp. 151-162).
} 
The first is that deflationism is prima facie plausible. It is one of the main contemporary theories of truth around and it is widely respected. It is beyond the scope of this paper to properly motivate and defend deflationism by discussing the merits and demerits of rival theories, but suffice it to say that the theory promises to explain a lot with very little. It promises to deflate the philosophical problem of truth, to explain the transparency of truth - the fact that we can move freely between ' $\mathrm{P}$ ' and 'It is true that $\mathrm{P}$ ' - to explain the usefulness of the term 'true', and to do all this without resorting to any kind of inflated metaphysics. So deflationism, while not a platitude, has a lot going for it.

The second is that even if deflationism is false and expressivists can't affirm that 'God is good' is true, expressivism might still be theologically acceptable. This is because expressivists can still affirm that God is good, even if deflationism is false. For they can do this by expressing their approval of God. That they can't say that 'God is good' is true is less problematic than it sounds, I submit, because it says more about the term 'true' than it does about God's goodness. It says that 'true' does not apply to 'God is good' perhaps because the sentence does not represent or robustly correspond with reality. But it does not say that God is not good, or that God is not really good. Because of this, I think that expressivism might still be theologically acceptable, even if deflationism is false. For expressivists can still affirm that God is good, and that God really is good, even if deflationism is false.

The third claim is thus false. So, if expressivism has unacceptable theological implications, it must be because it implies something else. This brings us on to the fourth and final claim.

\section{Expressivism and explanation}

According to the fourth and final claim, expressivism implies that there is no explanation why God has the moral thoughts that God does-why God has this set of moral thoughts, rather than some other set. If this is true, then one might think that expressivism has unacceptable theological implications because it implies that God's moral thoughts are mysteriously brute. Fortunately, expressivism does not imply this.

We should start by asking why we should take God to have moral thoughts, on expressivism. The answer, I take it, is that moral thoughts are practical or motivational thoughts, on expressivism. They are thoughts about what to do, what to allow, how to react, what to praise, what to blame, and so on (Blackburn, 1998, pp. 1, 312). If God lacked these thoughts, then God would be undecided about moral matters. That is to say, he would be undecided about whether $\mathrm{X}$ is to be done, whether $\mathrm{Y}$ is to be allowed, whether $\mathrm{Z}$ is to be praised or blamed, and so on. Since undecidedness is incompatible with being divine, we can conclude that God would have moral thoughts, even on expressivism.

But why does God have the moral thoughts that God does have, if expressivism is true? We can answer this question by considering Robert Adams' remarks on the divine nature. Adams writes: 
What I would suppose follows in the first instance from the divine nature is a certain general character of God's disposition and life, from which, to be sure, God's actions spring. Certain features of God's desires and aversions, likes and dislikes are determined in this way. We may suppose it is part of the divine nature, for instance, that God is generally disposed to rejoice in the joys, and dislike the suffering of any actual being, and would not want or will eternal misery for the innocent. (Adams, 1999, p. 47).

According to Adams, it is part of the divine nature that God has desire-like states. For example, that God dislikes the suffering of actual beings. If this is true-which it may well be-then expressivists can claim that it is part of the divine nature that God has moral thoughts. For example, that God thinks the suffering of actual beings is morally bad. For moral thoughts just are desire-like states, on expressivism. Consequently, expressivists can claim that just as it is part of the divine nature that God has desire-like states, it is part of the divine nature that God has moral thoughts. They can thus claim that the divine nature explains God's moral thoughts. That is, they can claim that God has the moral thoughts that God does because it is part of the divine nature that God has them.

One might object that even if the divine nature explains God's moral thoughts, expressivists are still left with a mysterious brute fact-that it is part of the divine nature that God has these moral thoughts. But if this is a problem, it is a general problem for theists, insofar as many theists wish to leave facts about the divine nature unexplained. For example, the fact that God is omnipotent, the fact that God is omniscient, and the fact that God is necessary. Moreover, it is not at all clear that theists should find unexplained facts about the divine nature theologically problematic. For if every fact about the divine nature were explained, that would seem to imply that there is something prior to God that explains his nature, which is theologically problematic. Expressivists should thus claim, I think, that God's moral thoughts are a brute part of the divine nature. Yes, this brute fact might be mysterious, but it is no more mysterious than other brute facts theists already accept.

The fourth claim is thus false. Expressivism does not imply that God's moral thoughts have no explanation, for expressivists can appeal to God's nature to explain God's moral thoughts. Expressivism thus has no unacceptable theological implications, or so I have argued.

\section{Conclusion}

Expressivism is the view that moral thoughts are desire-like states like approvals, desires, plans, preferences, intentions, and norm-acceptances. In this paper, I considered whether expressivism has unacceptable theological implications. That is, whether expressivism implies (1) that God's goodness depends on our desire-like states, (2) that God's goodness is not a real property, (3), that it is not true that God is good, and (4) that God's moral thoughts have no explanation. I argued that expressivism has no such implications and so conclude that expressivism is theologically acceptable. Expressivism should thus be considered a live option for theists. 
Acknowledgements I am very grateful to Alex Gregory, Brad Hooker, Jonathan Way, and Martin Dunkley Smith for helpful comments on earlier drafts of this paper. I am also grateful to members of the Postgraduate Research Seminar at the University of Southampton for their insightful feedback. This work was generously supported by the Arts and Humanities Research Council [AH/L503939/1].

Open Access This article is licensed under a Creative Commons Attribution 4.0 International License, which permits use, sharing, adaptation, distribution and reproduction in any medium or format, as long as you give appropriate credit to the original author(s) and the source, provide a link to the Creative Commons licence, and indicate if changes were made. The images or other third party material in this article are included in the article's Creative Commons licence, unless indicated otherwise in a credit line to the material. If material is not included in the article's Creative Commons licence and your intended use is not permitted by statutory regulation or exceeds the permitted use, you will need to obtain permission directly from the copyright holder. To view a copy of this licence, visit http://creativecommons.org/licen ses/by/4.0/.

\section{References}

Adams, R. M. (1999). Finite and infinite goods: A framework for ethics. Oxford University Press.

Berker, S. (2020). Quasi-dependence. In R. Shafer-Landau (Ed.), Oxford studies in metaethics (Vol. 15, pp. 195-218). Oxford University Press.

Blackburn, S. (1984). Speading the word. Oxford University Press.

Blackburn, S. (1993). Essays in quasi-realism. Oxford University Press.

Blackburn, S. (1998). Ruling passions. Oxford University Press.

Böddeling, A. (2020). Cognitivism and metaphysical weight: a dilemma for relaxed realism. Australasian Journal of Philosophy, 98(3), 546-559.

Gibbard, A. (1990). Wise choices, apt feelings: A theory of normative judgement. Oxford University Press.

Gibbard, A. (2003). Thinking how to live. Harvard University Press.

Golub, C. (2017). Expressivism and realist explanations. Philosophical Studies, 174(6), 1385-1409.

Hare, R. M. (1952). The language of morals. Oxford University Press.

Murphy, M. C. (2011). God and moral law: On the theistic explanation of morality. Oxford University Press.

Quinn, P. L. (1990). An argument for divine command ethics. In M. D. Beaty (Ed.), Christian theism and the problems of philosophy (pp. 289-302). University of Notre Dame Press.

Ridge, M. (2014). Impassioned belief. Oxford University Press.

Schroeder, M. (2010). Noncognitivism in ethics. Routledge.

Schroeder, M. (2014). Does expressivism have subjectivist consequences? Philosophical Perspectives, 28, 278-290.

Sinclair, N. (2008). Free thinking for expressivists. Philosophical Papers, 37(2), 263-287.

Sinclair, N. (2020). Ethical subjectivism and expressivism. Cambridge University Press.

Wielenberg, E. J. (2014). Robust ethics: The metaphysics and epistemology of godless normative realism. Oxford University Press.

Publisher's Note Springer Nature remains neutral with regard to jurisdictional claims in published maps and institutional affiliations. 